\title{
MSC response to $\mathrm{pH}$ levels found in degenerating intervertebral discs
}

\author{
Karin Wuertz, $\mathrm{PhD}^{1,2}$, Karolyn Godburn, $\mathrm{MS}^{1}$, and James C. latridis, $\mathrm{PhD}^{1}$ \\ ${ }^{1}$ School of Engineering, University of Vermont, Burlington, Vermont, United States of America ${ }^{2}$ Spine \\ Research Group, Competence Center for Applied Biotechnology and Molecular Medicine, University of \\ Zurich, Zurich, Switzerland
}

\begin{abstract}
Painful degenerative disc disease is a major health problem and for successful tissue regeneration, MSCs must endure and thrive in a harsh disc microenvironment that includes matrix acidity as a critical factor. MSCs were isolated from bone marrow of Sprague-Dawley rats from two different age groups $(<1$ month, $\mathrm{n}=6$ and $4-5$ months, $\mathrm{n}=6)$ and cultured under four different $\mathrm{pH}$ conditions representative of the healthy, mildly or severely degenerated intervertebral disc $(\mathrm{pH} 7.4, \mathrm{pH} 7.1, \mathrm{pH}$ 6.8 , $\mathrm{pH}$ 6.5) for 5 days. Acidity caused an inhibition of aggrecan, collagen- 1 and TIMP-3 expression, as well as a decrease in proliferation and viability and was associated with a change in cell morphology. Ageing had generally minor effects but young MSCs maintained greater mRNA expression levels. As acidic $\mathrm{pH}$ levels are typical of increasingly degenerated discs, our findings demonstrate the importance of early interventions and predifferentiation when planning to use MSCs for reparative treatments.
\end{abstract}

\section{Keywords}

intervertebral disc; mesenchymal stem cells; $\mathrm{pH}$; regeneration; gene expression; proliferation; viability; ageing

\section{Introduction}

Tissue engineering approaches for intervertebral disc repair and regeneration require a sufficient number of functional cells, and progenitor cells such as mesenchymal stem cells (MSCs) have attracted special attention. Progenitor cells may hold more promise than native cells isolated from the respective damaged tissue, since degenerative conditions diminishes functionality and total numbers of native cells available. Regenerative strategies for degenerative disc disease face multiple challenges, most of which evolve from the disc's uncommon and harsh microenvironment. The disc microenvironment is characterized by high mechanical loads [1], reduced oxygen supply [2] and reduced nutrition [3;4] as well as high [5]. Perhaps the most challenging microenvironment condition of the intervertebral disc is its

Corresponding Author: Dr. Karin Wuertz, PhD, Spine Research Unit, Competence Center for Applied Biotechnology and Molecular Medicine, University of Zurich, Winterthurerstrasse 190, 8057 Zurich, Switzerland, Email: wuertz@ vetbio.uzh.ch, Phone: 0041-44-653-5497, Fax: 0041-44-635-6840.

Publisher's Disclaimer: This is a PDF file of an unedited manuscript that has been accepted for publication. As a service to our customers we are providing this early version of the manuscript. The manuscript will undergo copyediting, typesetting, and review of the resulting proof before it is published in its final citable form. Please note that during the production process errors may be discovered which could affect the content, and all legal disclaimers that apply to the journal pertain. 
matrix acidity, which increases with degeneration [6]. The $\mathrm{pH}$ conditions in the disc are more pronounced than in cartilage [6;7], with the $\mathrm{pH}$ levels in a healthy disc ranging between 7.2 and 7.0 [8] and around $0.5 \mathrm{pH}$ units lower than that of surrounding fluids [5]. Matrix acidity can drop drastically during disc degeneration with $\mathrm{pH}$ levels of 6.5 most representative of severely degenerated discs, although values of pH 5.7 have been recorded [6;9] (Table 1).

Acidification during degenerative processes can be explained by a loss of nutrient transportation routes (e.g. due to smoking [10]) as well as by the presence of cytokines which may enhance lactic acid production [11;12]. In general, two main factors are responsible for the acidic conditions in the normal intervertebral disc: The disc is avascular and therefore energy metabolism is mostly based on anaerobic glycolysis, which means that disc cells produce ATP by transforming glucose into lactic acid [13].. In addition, the intervertebral disc is characterized by a high negative charged fixed density and therefore also by high concentrations of free cations [14] such as $\mathrm{H}^{+}$because of high proteoglycan concentrations.

Matrix acidity is known to play an important role in the functionality and viability of disc cells $[4 ; 14 ; 15]$ and was previously determined to be a crucial factor in MSC behavior [16]. Values of $\mathrm{pH}$ drop substantially in advanced degeneration making knowledge of $\mathrm{pH}$ effects on MSCs critical, however, the behavior of MSCs to varying $\mathrm{pH}$ environments remains largely uninvestigated and is the purpose of this study. The hypothesis of this study is that gene expression, proliferation and viability will be maintained at neutral $\mathrm{pH}$ but that function and viability of MSCs will be significantly reduced at $\mathrm{pH}$ levels below a certain threshold. The clinical relevance is to determine how different acidity levels affect MSC behavior in order to establish if a pH range exists when there is optimal likelihood of successful regenerative applications.

\section{Methods}

\section{Cell isolation and expansion}

Femurs from 12 Sprague-Dawley rats were bilaterally excised within 1 hour after death and the ends of the bones were removed. Six animals were $4-5$ months old and another six animals was 3-4 weeks old. The bone marrow was detached from the femur by a short centrifugation step (1500 rcf, 30 seconds). Bone marrow aspirates of both femurs of one rat were pooled and resuspended in culture medium consisting of DMEM with $10 \%$ FCS, Penicillin (100 units $/ \mathrm{ml})$, Streptoymcin $(100 \mu \mathrm{g} / \mathrm{ml})$ and Amphotericin $(2.5 \mu \mathrm{g} / \mathrm{ml})$. Freshly isolated cells of each rat were incubatred at $37^{\circ} \mathrm{C}, 5 \% \mathrm{CO}_{2}$ and $21 \% \mathrm{O}_{2}$ and after 24 hours, culture medium was changed to remove non-adherent cells, therefore identifying MSCs by the Colony Forming UnitFibroblast assay (CFU-F assay) [17] and expanded thereafter. All reagents were purchased from Invitrogen (Carlsbad, CA).

\section{Cell culture under IVD-typical pH conditions}

MSCs in passage 1 were trypsinized, resuspended in culture medium consisting of DMEM supplemented with $10 \%$ FCS, Penicillin (50 units $/ \mathrm{ml})$, Streptoymcin $(50 \mu \mathrm{g} / \mathrm{ml})$ and Amphotericin $(1.25 \mu \mathrm{g} / \mathrm{ml})$ and aliquoted into $25 \mathrm{~cm}^{2}$ cell culture flasks (gene expression analysis) or 24 well plates (all other analysis methods). Medium with 4 different $\mathrm{pH}$ values were prepared by adding an appropriate amount of $1 \mathrm{M} \mathrm{HCl}$, to the supplemented DMEM, resulting in $\mathrm{pH}$ values of 7.4 (= body fluid), 7.1 (= healthy IVD), 6.8 (= mildly degenerated IVD) and 6.5 (= severely degenerated IVD). The culture medium was kept in the incubator for 18 hours to allow $\mathrm{pH}$ equilibrium $\left(\mathrm{CO}_{2}\right.$-dependent) to be reached. Normal medium was replaced by the appropriate $\mathrm{pH}$ adjusted medium one day later, with each rat MSCs being cultured under 4 different $\mathrm{pH}$ conditions. On day 3 , medium was replaced by fresh, equilibrated $\mathrm{pH}$ medium and on day 5 , cells were harvested and analyzed. 


\section{Gene expression analysis (real-time RT PCR)}

MSCs were lysed and RNA was isolated by use of the GenElute mammalian total RNA Kit (Sigma, St. Louis, MO) and reverse transcribed into cDNA with MultiScribe reverse transcriptase using the TaqMan reverse transcription reagents (Applied Biosystems, Foster City, CA). For each sample, duplicate analysis of the mRNA levels were performed using realtime RT-PCR on the GeneAmp 7700 Sequence Detection System (Applied Biosystems, Foster City, CA) and the TaqMan Universal PCR Master Mix (Applied Biosystems, Foster City, CA). Gene expression of matrix proteins (aggrecan, collagen-1, collagen-2), matrix degrading enzymes (MMP-2, ADAMTS4), anti-catabolic genes (TIMP-3), apoptosis markers (p53, caspase-3) and a housekeeping gene (18S-RNA) was measured as previously described [18; 19] (for primer sequences see Table 2). Duplicate $C t$ values for each sample were analyzed and the relative amount of mRNA was computed according to the comparative $\mathrm{Ct}$ Method. For each rat, gene expression was calculated relative to 18S-RNA and gene expression at $\mathrm{pH} 7.1$, $\mathrm{pH} 6.8$ and $\mathrm{pH} 6.5$ was calculated relative to gene expression at $\mathrm{pH} 7.4$.

\section{Measurement of proliferation (MTT Assay)}

A fresh, sterile solution of MTT [3-(4,5-Dimethylthiazol-2-yl)-2,5-diphenyl tetrazolium bromide from Sigma, St. Louis, MO] with a concentration of $0.5 \mathrm{mg} / \mathrm{ml}$ in DMEM was prepared, $500 \mu \mathrm{l}$ was added to each well and incubated for 4 hours at $37^{\circ} \mathrm{C}$. MTT medium was discarded and $200 \mu \mathrm{l}$ sterile DMSO (Sigma, St. Louis, MO) was added to lyse cells (10 min, $37^{\circ} \mathrm{C}$, under shaking). Two aliquots were measured in duplicate at $565 \mathrm{~nm}$ and absorbance at $\mathrm{pH} 7.1, \mathrm{pH} 6.8$ and $\mathrm{pH} 6.5$ was calculated relative to the absorbance at $\mathrm{pH}$ 7.4.

\section{Analysis of DNA content (Picrogreen Assay)}

DNA content of samples was analyzed using the Picogreen dsDNA quantitation Kit (Invitrogen, Carlsbad, CA). Briefly, MSCs were trypsinized, centrifugated and the cell pellet was digested with $400 \mu \mathrm{l}$ of sterile papain solution at $60^{\circ} \mathrm{C}$ over night $[\mathrm{NaOAc}(100 \mathrm{mM})$,

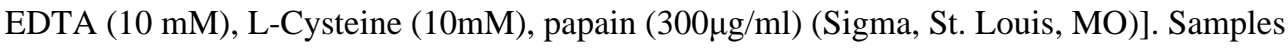
( $50 \mu \mathrm{l}$, in duplicate) were incubated with Picogreen dsDNA quantitation Kit in a 96 well plate and quantified photometrically (extinction $480 \mathrm{~nm}$, emission $520 \mathrm{~nm}$ ) relative to DNA standards.

\section{Analysis of cell viability (Fluoresceindiacetate/Propidiumiodide Staining)}

A fresh, sterile staining solution with a concentration of $20.8 \mu \mathrm{g}$ Fluoresceindiacetate (in Acetone) and $16.7 \mu \mathrm{g}$ Propidiumiodide (in Ringer) (Sigma, St. Louis, MO) per $1 \mathrm{ml}$ Ringer was prepared, $500 \mu \mathrm{l}$ were added to each well and incubated in the dark at $37^{\circ} \mathrm{C}$ for $20 \mathrm{~min}$. After incubation, cells were washed with sterile PBS (3x) and an inverted fluorescence microscope was used to detect red and green fluorescence, determining the ratio of viable to $\mathrm{dead} /$ necrotic cells under each $\mathrm{pH}$ conditions.

\section{Statistical Analysis}

A two way ANOVA was performed to evaluate effects of $\mathrm{pH}$ level (repeated measures) and aging (young vs mature). Post-hoc comparisons were performed using Dunnet's test to evaluate effects of $\mathrm{pH}$ using $\mathrm{pH} 7.4$ as control. When significant interactions between $\mathrm{pH}$ and age were found, Fisher's PLSD was performed to evaluate the $\mathrm{pH}$ levels where young and mature donors had significant differences. All analyses were performed using StatView (Version 5.0.1., SAS Institute Inc., Cary, NC, USA) with a significance level of $\mathrm{p}<0.05$. 


\section{Results}

\section{Gene expression (real-time RT-PCR)}

The $\mathrm{pH}$ conditions strongly influenced gene expression (Figure 1), with a significant inhibition of mRNA levels for aggrecan, collagen-1 and TIMP-3 expression under acidic conditions relative to $\mathrm{pH} 7.4$, with severe effects already at $\mathrm{pH} 6.8$ for aggrecan and at $\mathrm{pH} 6.5$ for collagen- 1 and TIMP-3. Effects for collagen-1 were less pronounced than for aggrecan. Only minor or no changes in the expression of MMP-2 and caspase- 3 were detected until $\mathrm{pH}$ levels were reduced all the way to 6.5 . The mRNA expression of collagen- 2 and p53 were under the detection level and could not be analyzed. Some age effects were noted with $\mathrm{pH}$ having a larger effect on the down-regulation of TIMP-3 for mature MSCs at $\mathrm{pH} 7.1$ and 6.8. The young MSCs up-regulated MMP-2 expression at $\mathrm{pH} 7.1$ and 6.8 while mature MSCs showed hardly any alterations of MMP-2 mRNA levels at the same pH levels. In summary, acidity caused a drop in relative biosynthesis rate (aggrecan, collagen-1, TIMP-3) in our cell culture experiments, particularly for mature cells with evidence of a decreased biosynthesis rate and altered phenotype with age.

\section{Cell proliferation (MTT assay)}

Cell proliferation was also strongly influenced by $\mathrm{pH}$ (Figure 2A), with proliferation being highest for $\mathrm{pH} 7.4$ and 7.1 and decreasing at more acidic $\mathrm{pH}$ conditions with no effects of rat age. We found a significant inhibition of proliferation for all $\mathrm{pH}$ levels compared to 7.4.

\section{DNA content (Picogreen assay)}

Measurement of DNA content revealed a dose-dependent decrease that was statistically significant from $\mathrm{pH} 7.4$ for $\mathrm{pH} 6.8$ and 6.5 (Figure 2B) and showed high similarities to data obtained via MTT assay (as shown in Figure 2A). There was a significant effect of animal age at $\mathrm{pH} 6.8$ and 7.1, but this effect was of small magnitude and results were generally consistent for both age groups.

\section{Cell viability (fluoresceindiacetate/propidiumiodide)}

Cell viability decreased with acidity, showing a decreased number of living cells (green) and an increased number of dead cells (red) from $\mathrm{pH} 7.4$ to $\mathrm{pH} 6.5$ (Figure 3), with the most severe effects occurring below pH 6.8. Morphological changes were also noted as MSCs showed a loss in cytoskeleton size under acidic $\mathrm{pH}$ conditions. The total number of cells also decreased from $\mathrm{pH} 7.4$ to $\mathrm{pH}$ 6.5, therefore supporting the data obtained from MTT and Picogreen assay. No differences were observed between cells from young and mature animals.

\section{Discussion}

The intervertebral disc is characterized by an acidic $\mathrm{pH}$, especially during the process of disc degeneration. Matrix acidity may negatively influence disc cell functionality and may also limit the success of MSC based tissue regeneration for the intervertebral disc. To date, this is the first study to directly investigate the responses of MSCs to $\mathrm{pH}$ levels found in the disc, and we used a cell culture system to address several clinically important questions: Is there a $\mathrm{pH}$ level where biosynthesis rates of MSCs are greatly diminished? Does $\mathrm{pH}$ cause phenotypic changes? At what $\mathrm{pH}$ level do MSCs stop proliferating and lose viability? Does donor age affect the response of MSCs to $\mathrm{pH}$ ?

This study revealed a drop in biosynthesis rate, as indicated by the down-regulation of aggrecan, collagen-1 and TIMP-3 mRNA expression, that occurred with increasing acidity, as would be expected with advanced disc degeneration. It was noteworthy that functionality and viability were generally maintained at $\mathrm{pH} 7.1$ (representing a fairly healthy disc) while significant loss of cellularity and decreased biosynthesis rates were found at $\mathrm{pH} 6.5$ (representing a severely 
degenerated disc). This decrease in mRNA expression was gradual with decreasing $\mathrm{pH}$ particularly for MSCs from mature donor animals (especially when considering the logarithmic nature of the $\mathrm{pH}$ scale). While MSCs from young and mature donors reacted similarly, anabolic and catabolic mRNA expression was maintained at (or even increased) in young MSCs with $\mathrm{pH}$ values as low as 6.8 suggesting more of a threshold response compared to mature MSCs.

Gene expression and morphology results further indicated $\mathrm{pH}$ levels affected phenotype as well as biosynthesis rates. The decrease in anabolicand anti-catabolic mRNA measurements as well as the general lack of change (or increase) in MMP-2 expression at all but the lowest $\mathrm{pH}$ level suggested a shift to a more catabolic response. In a study by Bischoff et al., it was shown that a drop in $\mathrm{pH}$ can stimulate IL-8 production (via $\mathrm{p} 38$ and NFKB pathways) [20] and certain cytokines are known to influence matrix protein expression and production [21], which may be a potential mechanism for findings in this study, although more investigation is necessary to determine underlying pathways for our observed changes.

A drop in $\mathrm{pH}$ revealed negative effects on proliferation and viability of MSCs as indicated by MTT assay, Picogreen assay and viability staining. For other cell types such as fibroblasts, pH was already shown to control proliferation as well as expression of extracellular matrix proteins [22]. In addition to showing an increase in apoptotic/necrotic cells under more acidic conditions, viability staining also indicated a change in cell morphology from cells with a large cytoskeleton to roundish small cells. The change in cytomorphology and the shift in mRNA expression further support an altered phenotype with acidity prior to, or concomitant with, loss of cellularity. Cytomorphological alteration may have arisen due to (1) changes in cytoskeleton, (2) changes in cell adhesion molecules [23] or (3) survival and therefore selection of a certain cell type from the heterogeneous MSC pool. Further characterization of the remaining cells will be necessary to develop appropriate interventions.

Even though viability staining revealed a $\mathrm{pH}$ dependency, it was difficult to make conclusions about apoptotic processes. Measurement of caspase- 3 expression did not show significant effects of $\mathrm{pH}$ condition, which might be due to the fact that expression of caspase- 3 is an early apoptosis marker that may have reached a plateau or steady state after 5 days of culture. When culturing fibroblasts at acidic $\mathrm{pH}$ levels ( $\mathrm{pH}$ 6.7) for shorter time periods (1-3 days), an increase in the expression of certain apoptosis markers such as FLAME-1 or TRAIL APO2-L could be observed by proteomics [24]. Expression of p53 was also evaluated in this study but was not detectable (even though the primers/probe were shown to be efficient on RNA isolated from disc tissue) which suggests additional cells in pellet and/or 3-D culture would be important for future studies.

Matrix acidity seems to be more detrimental to MSCs than to disc cells when compared to the literature. Bovine nucleus pulposus cells showed a decrease in synthesis of sulphated glycosaminoglycans below pH 6.8 (compared to $\mathrm{pH} 7.2$ ), measured by ${ }^{35} \mathrm{~S}$-sulphate incorporation [14;15]; incorporation of ${ }^{3} \mathrm{H}$-Proline was shown to be less sensitive to extracellular $\mathrm{pH}$ [15]. In a similar culture system, Bibby et al. found a decrease in cell viability when decreasing the $\mathrm{pH}$ to 6.7 and a more obvious decrease for $\mathrm{pH} 6.2$, especially when culturing cells under nutrient deficit conditions [3]. We hypothesize that differentiated cells (disc cells) are better adapted to the harsh $\mathrm{pH}$ conditions than undifferentiated stem cells such as our nascent MSCs. Intervertebral disc cells express acid sensing ion channel proteins (ASIC), which was shown to be likely associated to their ability to survive under acidic conditions [25] and this may be responsible for observed differences. One way for successful disc regeneration may be the use of predifferentiated MSCs, using growth factors such as TGFbeta [26], or to subject MSCs to a more gradual acclimation to altered $\mathrm{pH}$ as would occur in vivo. This hypothesis is supported by a recent study from Guehring et al., showing that notochordal cells are also more sensitive to changes in $\mathrm{pH}$ than disc cells [27], which could be 
due to the gradual increase in acidity that occurs with disc cells throughout aging and degeneration.

The choice for 2D culture allowed high proliferation rates and high cell yields while keeping passage number low, yet had some limitations, particularly with regard to defining cell phenotype. For example collagen-2 mRNA was hardly detectable, possibly due to the use of a 2D system [28], especially as primers/probe were successfully used before on disc tissue $[18 ; 19]$. More precise evaluation of cell phenotype would require a 3D culture system. This study determined that donor age may be an important factor for MSC regeneration; future studies with an aged group would provide additional insight beyond the effects of maturation as explored in the current study, yet our relatively young age groups were expected to represent cells with the most promise for adaptation to media $\mathrm{pH}$ changes.

Results indicated that MSC functionality, phenotype, and viability were minimally restricted at $\mathrm{pH} 7.1$, representing a fairly healthy disc, and severely compromised at $\mathrm{pH} 6.5$, representing a severely degenerated disc. The MSC response to $\mathrm{pH}$ levels was gradual although there was some evidence that cells from young donors might exhibit a response with maintained biosynthesis rates until a lower $\mathrm{pH}$ threshold. We conclude that MSC therapies for degenerative disc regeneration offer the greatest promise when applied at early stages of degeneration with $\mathrm{pH}$ levels of 6.8 or above. Findings also suggested a likelihood of failure for MSC based regeneration in severely degenerated discs using nascent MSCs. However, $\mathrm{pH}$ challenges are less detrimental to disc cells than to MSCs, and we speculate that treatment of moderately and severely degenerated IVDs may be possible using MSCs after predifferentiation and/or more gradual acclamation of cells to matrix acidity.

\section{Acknowledgements}

Supported by a grant from the National Institutes of Health (R01 AR051146) and AO Research Foundation.

\section{References}

1. Wilke HJ, Neef P, Caimi M, Hoogland T, Claes LE. New in vivo measurements of pressures in the intervertebral disc in daily life. Spine 1999;24:755-62. [PubMed: 10222525]

2. Grunhagen T, Wilde G, Soukane DM, Shirazi-Adl SA, Urban JP. Nutrient supply and intervertebral disc metabolism. J Bone Joint Surg Am 2006;88(Suppl 2):30-5. [PubMed: 16595440]

3. Bibby SR, Jones DA, Ripley RM, Urban JP. Metabolism of the intervertebral disc: effects of low levels of oxygen, glucose, and $\mathrm{pH}$ on rates of energy metabolism of bovine nucleus pulposus cells. Spine 2005;30:487-96. [PubMed: 15738779]

4. Bibby SR, Urban JP. Effect of nutrient deprivation on the viability of intervertebral disc cells. Eur Spine J 2004;13:695-701. [PubMed: 15048560]

5. Urban JP. The role of the physicochemical environment in determining disc cell behaviour. Biochem Soc Trans 2002;30:858-64. [PubMed: 12440933]

6. Kitano T, Zerwekh JE, Usui Y, Edwards ML, Flicker PL, Mooney V. Biochemical changes associated with the symptomatic human intervertebral disk. Clin Orthop Relat Res 1993:372-7. [PubMed: 8339506]

7. Grodzinsky AJ. Electromechanical and physicochemical properties of connective tissue. Crit Rev Biomed Eng 1983;9:133-99. [PubMed: 6342940]

8. Ichimura K, Tsuji H, Matsui H, Makiyama N. Cell culture of the intervertebral disc of rats: factors influencing culture, proteoglycan, collagen, and deoxyribonucleic acid synthesis. J Spinal Disord 1991;4:428-36. [PubMed: 1810565]

9. Diamant B, Karlsson J, Nachemson A. Correlation between lactate levels and $\mathrm{pH}$ in discs of patients with lumbar rhizopathies. Experientia 1968;24:1195-6. [PubMed: 5703005]

10. Holm S, Nachemson A. Nutrition of the intervertebral disc: acute effects of cigarette smoking. An experimental animal study. Ups J Med Sci 1988;93:91-9. [PubMed: 3376356] 
11. Kang JD, Georgescu HI, McIntyre-Larkin L, Stefanovic-Racic M, Donaldson WF 3rd, Evans CH. Herniated lumbar intervertebral discs spontaneously produce matrix metalloproteinases, nitric oxide, interleukin-6, and prostaglandin E2. Spine 1996;21:271-7. [PubMed: 8742201]

12. Tetlow LC, Adlam DJ, Woolley DE. Matrix metalloproteinase and proinflammatory cytokine production by chondrocytes of human osteoarthritic cartilage: associations with degenerative changes. Arthritis Rheum 2001;44:585-94. [PubMed: 11263773]

13. Holm S, Maroudas A, Urban JP, Selstam G, Nachemson A. Nutrition of the intervertebral disc: solute transport and metabolism. Connect Tissue Res 1981;8:101-19. [PubMed: 6453689]

14. Razaq S, Wilkins RJ, Urban JP. The effect of extracellular $\mathrm{pH}$ on matrix turnover by cells of the bovine nucleus pulposus. Eur Spine J 2003;12:341-9. [PubMed: 12883962]

15. Ohshima H, Urban JP. The effect of lactate and $\mathrm{pH}$ on proteoglycan and protein synthesis rates in the intervertebral disc. Spine 1992;17:1079-82. [PubMed: 1411761]

16. Wuertz K, Godburn K, Neidlinger-Wilke C, Urban J, Iatridis JC. Behavior of mesenchymal stem cells in the chemical microenvironment of the intervertebral disc. Spine 2008;33:1843-9. [PubMed: 18670337]

17. Friedenstein AJ, Chailakhjan RK, Lalykina KS. The development of fibroblast colonies in monolayer cultures of guinea-pig bone marrow and spleen cells. Cell Tissue Kinet 1970;3:393-403. [PubMed: 5523063]

18. Maclean JJ, Lee CR, Alini M, Iatridis JC. Anabolic and catabolic mRNA levels of the intervertebral disc vary with the magnitude and frequency of in vivo dynamic compression. J Orthop Res 2004;22:1193-200. [PubMed: 15475197]

19. MacLean JJ, Lee CR, Alini M, Iatridis JC. The effects of short-term load duration on anabolic and catabolic gene expression in the rat tail intervertebral disc. J Orthop Res 2005;23:1120-7. [PubMed: 16140193]

20. Bischoff DS, Zhu JH, Makhijani NS, Yamaguchi DT. Acidic $\mathrm{pH}$ stimulates the production of the angiogenic CXC chemokine, CXCL8 (interleukin-8), in human adult mesenchymal stem cells via the extracellular signal-regulated kinase, p38 mitogen-activated protein kinase, and NF-kappaB pathways. J Cell Biochem 2008;104:1378-92. [PubMed: 18275043]

21. Le Maitre CL, Freemont AJ, Hoyland JA. The role of interleukin-1 in the pathogenesis of human intervertebral disc degeneration. Arthritis Res Ther 2005;7:R732-45. [PubMed: 15987475]

22. Borsi L, Allemanni G, Gaggero B, Zardi L. Extracellular pH controls pre-mRNA alternative splicing of tenascin-C in normal, but not in malignantly transformed, cells. Int J Cancer 1996;66:632-5. [PubMed: 8647625]

23. Serrano CV Jr, Fraticelli A, Paniccia R, Teti A, Noble B, Corda S, Faraggiana T, Ziegelstein RC, Zweier JL, Capogrossi MC. pH dependence of neutrophil-endothelial cell adhesion and adhesion molecule expression. Am J Physiol 1996;271:C962-70. [PubMed: 8843727]

24. Bumke MA, Neri D, Elia G. Modulation of gene expression by extracellular $\mathrm{pH}$ variations in human fibroblasts: a transcriptomic and proteomic study. Proteomics 2003;3:675-88. [PubMed: 12748947]

25. Uchiyama Y, Cheng CC, Danielson KG, Mochida J, Albert TJ, Shapiro IM, Risbud MV. Expression of Acid-Sensing Ion Channel 3 (ASIC3) in Nucleus Pulposus Cells of the Intervertebral Disc is Regulated by p75NTR and ERK Signaling. J Bone Miner Res. 2007

26. Steck E, Bertram H, Abel R, Chen B, Winter A, Richter W. Induction of intervertebral disc-like cells from adult mesenchymal stem cells. Stem Cells 2005;23:403-11. [PubMed: 15749935]

27. Guehring, T.; Sumner, M.; Wilde, G.; Urban, JP. Notochordal Cells Diappearance In The Human Intervertebral Disc - The Role Of Nutritional Demands. Annual Meeting of the International Society for the Study of the Lumbar Spine; Hong Kong. 2007.

28. Marlovits S, Hombauer M, Truppe M, Vecsei V, Schlegel W. Changes in the ratio of type-I and typeII collagen expression during monolayer culture of human chondrocytes. J Bone Joint Surg $\mathrm{Br}$ 2004;86:286-95. [PubMed: 15046449] 

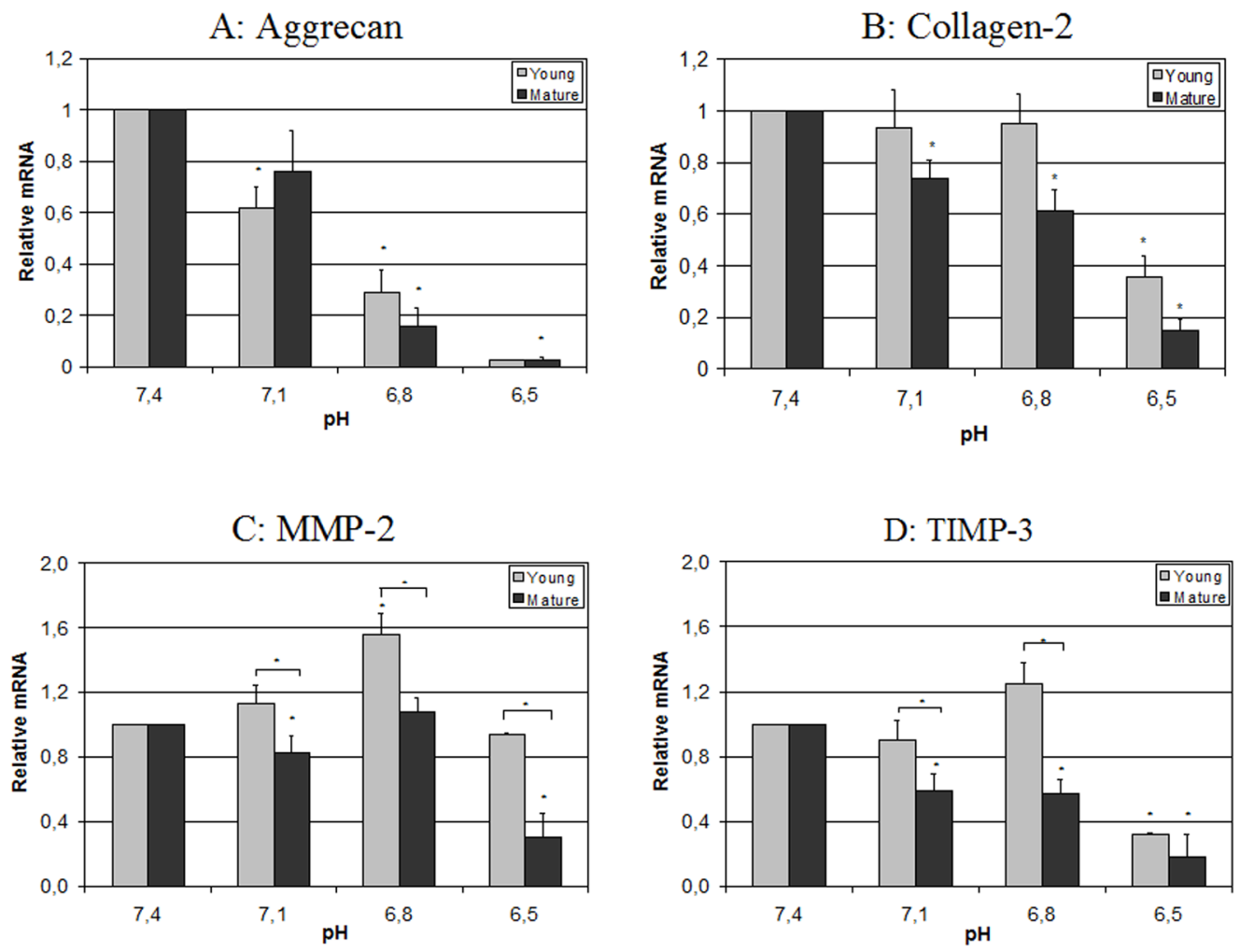

Figure 1.

Aggrecan (A), collagen-1 (B), TIMP-3 (C) and MMP-2 (D) mRNA expression under different $\mathrm{pH}$ levels, relative to $\mathrm{pH} 7.4$ (real-time RT-PCR). Statistically significant differences $(\mathrm{p}<0.05)$ are marked with *. 

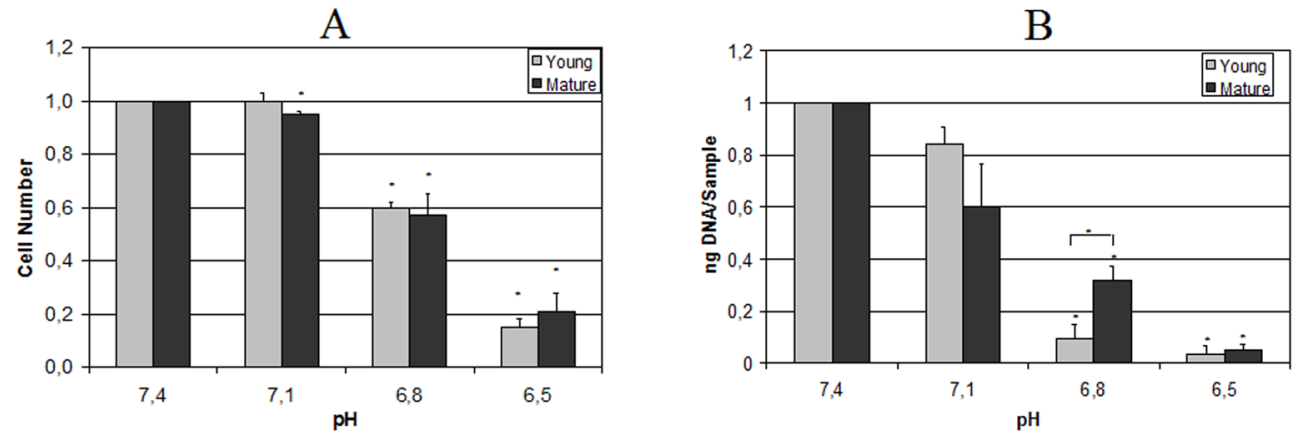

Figure 2.

A) Cell proliferation under different $\mathrm{pH}$ levels, relative to $\mathrm{pH} 7.4$ (MTT assay).

B) DNA content under different $\mathrm{pH}$ levels, relative to $\mathrm{pH} 7.4$ (Picogreen assay). Statistically significant differences $(\mathrm{p}<0.05)$ are marked with *. 

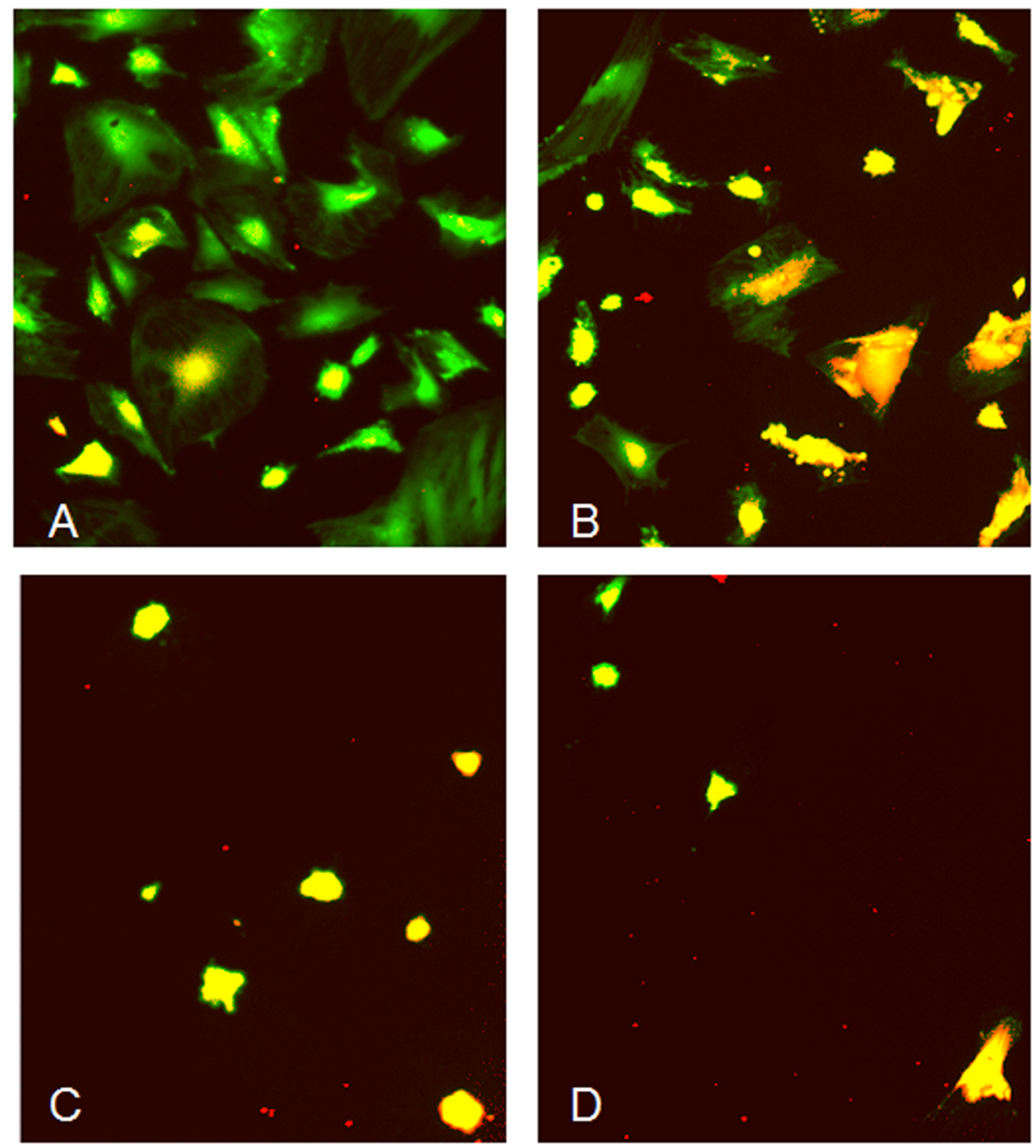

Figure 3.

Cell viability and morphology under different $\mathrm{pH}$ levels, where green fluorescence indicates viable cells (fluoresceindiacetate) and red indicates dead/necrotic cells (propidiumiodide). Pictures represent pH levels of 7.4 (A), 7.1 (B), 6.8 (C) and 6.5 (D). 
Table 1

Extracellular pH in the Intervertebral Disc.

\begin{tabular}{|r|l|l|}
\hline $\mathbf{p H}$ & Representative of & Reference \\
\hline 7.4 & Most body fluids & 14 \\
\hline 7.1 & Healthy IVD & 8 \\
\hline 6.8 & $\begin{array}{l}\downarrow \text { mild IVD degeneration } \\
\downarrow \text { moderate IVD degeneration } \\
\downarrow \text { severe IVD degeneration }\end{array}$ & 6,9 \\
\cline { 1 - 1 } 6.5 & & \\
\cline { 1 - 2 } 6.2 & & \\
\hline
\end{tabular}


Table 2

Primer/Probe sequences for real-time RT-PCR.

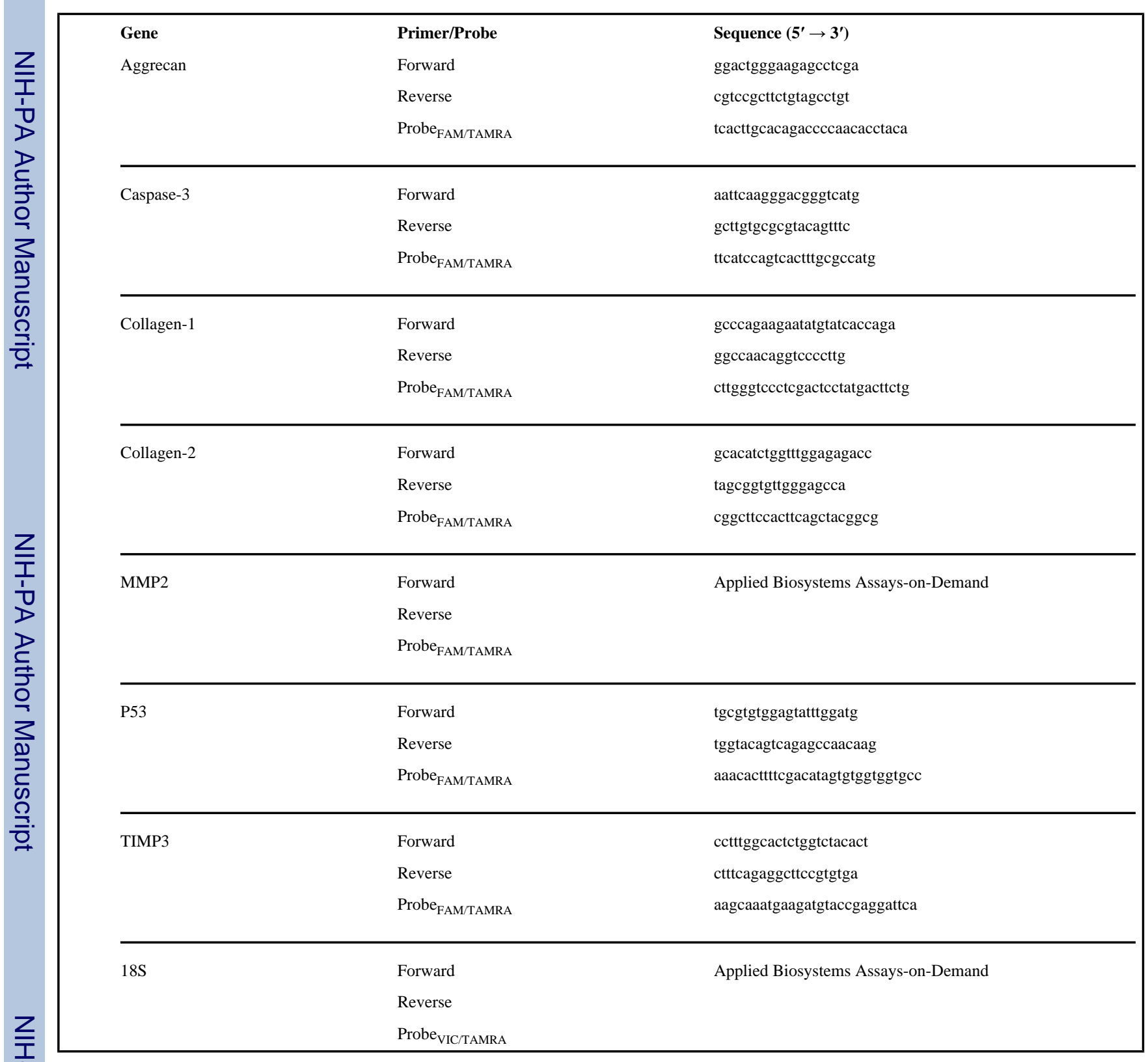

